\title{
Meta-Analysis of BRCA7 Polymorphisms and Breast Cancer Susceptibility
}

\author{
Metaanalýza polymorfizmů v BRCA1 a náchylnost $\mathrm{k}$ nádorům prsu
}

\author{
Ghafouri-Fard S., Dianatpour A., Faramarzi S. \\ Department of Medical Genetics, Shahid Beheshti University of Medical Sciences, Tehran, Iran
}

\begin{abstract}
Summary
Background: BRCA1 codes for a tumor suppressor protein involved in DNA repair. Based on the role of single nucleotide polymorphisms (SNPs) in the modification of gene expression and function and the existence of certain SNPs within $3^{\prime}$-untranslated region of BRCA1 with the ability to change binding sites for mirRNAs, several association studies have been designed to explore the significance of SNPs within BRCA1 gene in conferring breast cancer $(B C)$ risk. This study aims to assess the relationship between BRCA1 SNPs and BC using meta- analysis. Aim: To conduct a meta-analysis for retrieving case-control studies on the associations between the rs11655505, rs1799966, rs3737559, rs1799950, rs799917 and rs16941 BRCA1 polymorphisms and $B C$. The pooled odds ratios and its $95 \%$ confidence intervals were measured using fixed and random model to define the association between these polymorphisms and BC risk. Conclusion: No significant association was found for any of these polymorphisms and $\mathrm{BC}$ risk in the allelic, homozygote, dominant or recessive models. Overall, our study implies that the mentioned polymorphisms are not associated with BC risk. However, our study did not exclude the possible contribution of other SNPs within this gene in BC nor substantial contribution of multiple variants within this gene in conferring $B C$ risk.
\end{abstract}

Key words

BRCA1 - breast cancer - meta-analysis

\section{Souhrn}

Východiska: BRCA1 kóduje nádorově supresorový protein, který je zapojen do DNA oprav. Na základě role jednonukleotidových polymorfizmů (SNPs) v modifikaci genové exprese a funkce a existence některých SNP $\vee$ 3'-nepřekládané oblasti genu BRCA1 se schopností změny vazebných míst pro miRNA bylo publikováno několik asociačních studií za účelem zjištění významu SNP $\vee$ oblasti genu $B R C A 1$ ve srovnání s rizikem nádoru prsu (BC). Tato studie se zaměřila na zjištění vztahu mezi SNP v $B R C A 1$ a BC při použití metaanalýzy. Cíl: Provést metaanalýzu ze studií, které se zaměřily na asociaci mezi BRCA1 polymorfizmy rs11655505, rs1799966, rs3737559, rs1799950, rs799917 a rs16941 a BC. Sloučené poměry pravděpodobnosti a intervaly spolehlivosti na hladině $95 \%$ byly měřeny za použití pevného a náhodného modelu za účelem definovat souvislost mezi těmito polymorfizmy a rizikem $B C$. Závěr: $U$ žádného $z$ těchto polymorfizmů nebylo nalezeno žádné významné spojení v alelických, homozygotních, dominantních nebo recesivních modelech $s$ rizikem $B C$. Celkově naše studie naznačuje, že zmíněné polymorfizmy nejsou spojeny s rizikem BC. Nicméně naše studie nevylučovala ani možný prínos jiných SNP $v$ tomto genu $v \mathrm{BC}$ ani významný prínos více variant v rámci tohoto genu při určování rizik $\mathrm{BC}$.
The authors declare they have no potential conflicts of interest concerning drugs, products, or services used in the study.

Autor̆i deklarují, že $v$ souvislosti s předmětem studie nemaji žádné komerční zájmy.

The Editorial Board declares that the manuscript met the ICMJE recommendation for biomedical papers.

Redakční rada potvrzuje, že rukopis práce splnil ICMJE kritéria pro publikace zasilané do biomedicínských časopisů.

\section{$\equiv$}

Soudeh Ghafouri-Fard, MD, PhD Department of Medical Genetics Shahid Beheshti University of Medical Sciences

Bldg No.2 SBUMS

Arabi Ave, Daneshjoo Blvd, Velenjak Tehran, Iran

e-mail: s.ghafourifard@sbmu.ac.ir

Submitted/Obdrženo: 21. 5. 2018

Accepted/Přijato: 27.62018

doi: 10.14735/amko2018330

Klíčová slova

$B R C A 1$ - nádory prsu - metaanalýza 


\section{Introduction}

Breast cancer (BC) as the most common malignancy among women is associated with high mortality and morbidity [1]. Several susceptibility loci have been detected for this disorder [2-4]. BRCA1, located on chromosome $17 q 21$, has been the first cancer susceptibility gene detected through a linkage study in families with early onset of the disease [5]. BRCA1 gene as a prototype of tumor suppressor genes participates in protection of intact chromosome structure [6]. Highly penetrant variants of this gene explain less than $20 \%$ of the genetic risk of $B C$ [7]. The polygenic model for $\mathrm{BC}$ emphasizes the existence of numerous low penetrance high risk alleles that totally confer BC risk [8]. Consequently, more common variants in BRCA1 might also been associated with $B C$ risk [8]. Considering the role of single nucleotide polymorphisms (SNPs) in modification of gene expression and function and the existence of certain SNPs within 3'-untranslated region of $B R C A 1$ with the ability to change binding sites for microRNAs (miRNAs), several association studies have been designed to explore the significance of SNPs within the BRCA1 gene in conferring $B C$ risk [9-11]. However, discrepancies have been detected in the results of such studies, which can be attributed to the heterogeneity of patients' samples, small sample sizes and ethnic origin of patients. Consequently, we conducted a systematic search and meta-analysis to reach a more accurate answer to the question regarding the extent of the contribution of $B R C A 1$ genomic variants in $B C$ susceptibility.

\section{Methods}

\section{Search for relevant articles}

To find suitable studies for the present meta-analysis, we searched in the PubMed, Google Scholar, EMBASE and Web of Science databases until January 2018 using the following key words - 'breast cancer' or 'breast tumor' with 'BRCA1 gene polymorphism' or 'BRCA1 gene single nucleotide polymorphism' or 'BRCA1 gene SNPs' or 'BRCA1 gene SNP'. Besides, the articles were filtered with the terms 'rs11655505' or 'rs1799966' or 'rs3737559' or 'rs1799950' or 'rs799917' or 'rs16941'.We confined searches to full English articles. The collected studies were entered in the meta-analysis if a) the study provided association between the BRCA1 genetic polymorphisms and the susceptibility to $\mathrm{BC}, \mathrm{b})$ the study was designed as a casecontrol study, c) genotype/allele data of the polymorphism(s) were provided in the study. Case reports, editorials and cell culture experiments were excluded from the meta-analysis. Schema 1 shows the process of selection of studies for inclusion in the meta-analysis.

5,560 citations identified in PubMed, EMBASE and Google Scholar according to search strategy

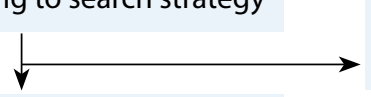

4,978 were excluded based on reading titles and abstracts

582 reports were reviewed for inclusion

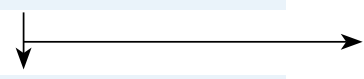

487 were filtered (review publications, meta-analysis, duplicate publications, not case control study, not English etc.)

95 full-text articles retrieved for detailed evaluation

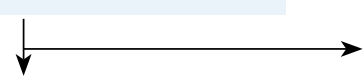

79 publications were excluded due to lack of sufficient data

(lack of genotype data,

16 studies included in the meta-analysis no matched control group etc.)

Schema 1. A systematic flow chart demonstrating the course of selection of articles for this meta-analysis.

\section{Data extraction}

All manuscripts were evaluated by two authors (Dianatpour A. and Faramarzi S.) according to the inclusion and exclusion criteria. The first author's name, year of publication, ethnicity of study participants, source of DNA (blood or breast tissue) used for SNP genotyping, total number of cases and controls and genotype distribution were collected. The studies were scored based on the Newcastle-Ottawa scale (NOS), [12] and those with NOS scores more than 6 were chosen for Hardy-Weinberg equilibrium (HWE) analysis.

\section{Statistical analysis}

The analyses were carried out in SPSS version 20 (IBM Analytics, USA) and RevMan version 5.3. The association between BRCA1 polymorphism (rs11 655505, rs1799966, rs3737559, rs1799 950, rs799917 and rs16941), and susceptibility of BC was assessed from the case-control studies through evaluation of odds ratios and $95 \%$ confidence intervals $(\mathrm{Cl})$. Moreover, we computed the pooled odds ratios and $\mathrm{Cls}$ for each SNP and assessed their significance of association with $B C$ risk using $P$ values in four genetic models including allelic (wild type (W) vs. minor (M)), homozygote (WW vs. MM), dominant (WW+WM vs. $M M$ ) and recessive (WW vs. WM+MM). Chi-square based $\mathrm{Q}$ statistic test and $I^{2}$ statistics were applied for assessment of the heterogeneity between the selected studies. Based on the value of $\mathrm{I}^{2}$, the random-effects (DerSimonian and Laird's method) or fixed effects model were applied. The results were demonstrated as forest and funnel plots, which show the association of $B R C A 1$ genetic polymorphisms with $B C$ and the possible existence of publication bias in the meta-analysis, respectively (Tab. 1).

\section{Results}

Features of studies included in the meta-analysis

After initial screening of relevant publications, 95 full text original researches were found. After exclusion of papers with insufficient genotype data and matched control groups, 16 studies remained. 
Tab. 1. Association between the individual study characteristics and BRCA1 polymorphisms.

\section{First author's name rs11655505} Year Country $\begin{aligned} & \text { Source } \\ & \text { of DNA }\end{aligned}$ Verderio et al. 2009 China blood 2009 several blood Hasan et al. 2012 India

Bielinska et al. 2013 Poland blood Hasan et al. 2013 India blood

\section{rs1799966}

Johnson et al. 2007 UK blood Dombernowsky 2009 Denmark blood et al.

Wu et al. 2013 several blood

\section{rs3737559}

Baynes et al. 2007 UK blood AL-Eitan et al. 2017 Jordan blood

\section{rs1799950}

Cox

Cox et al.

2005 USA blood

Baynes et al.

2007 UK blood

Seymour et al. 2007 Italy blood

Johnson et al. 2007 UK blood

Dombernowsky 2009 Denmark blood

et al.

\section{rs799917}

Huo et al.

Dombernowsky et al.

Wang et al. 2009 China

Wu et al. 2013 several

Hasan et al. 2013 Saudi blood

$\begin{array}{lc}\text { Genotype } & \begin{array}{c}\text { Genotype } \\ \text { frequency }\end{array} \\ \text { in controls } & \text { in cases }\end{array}$




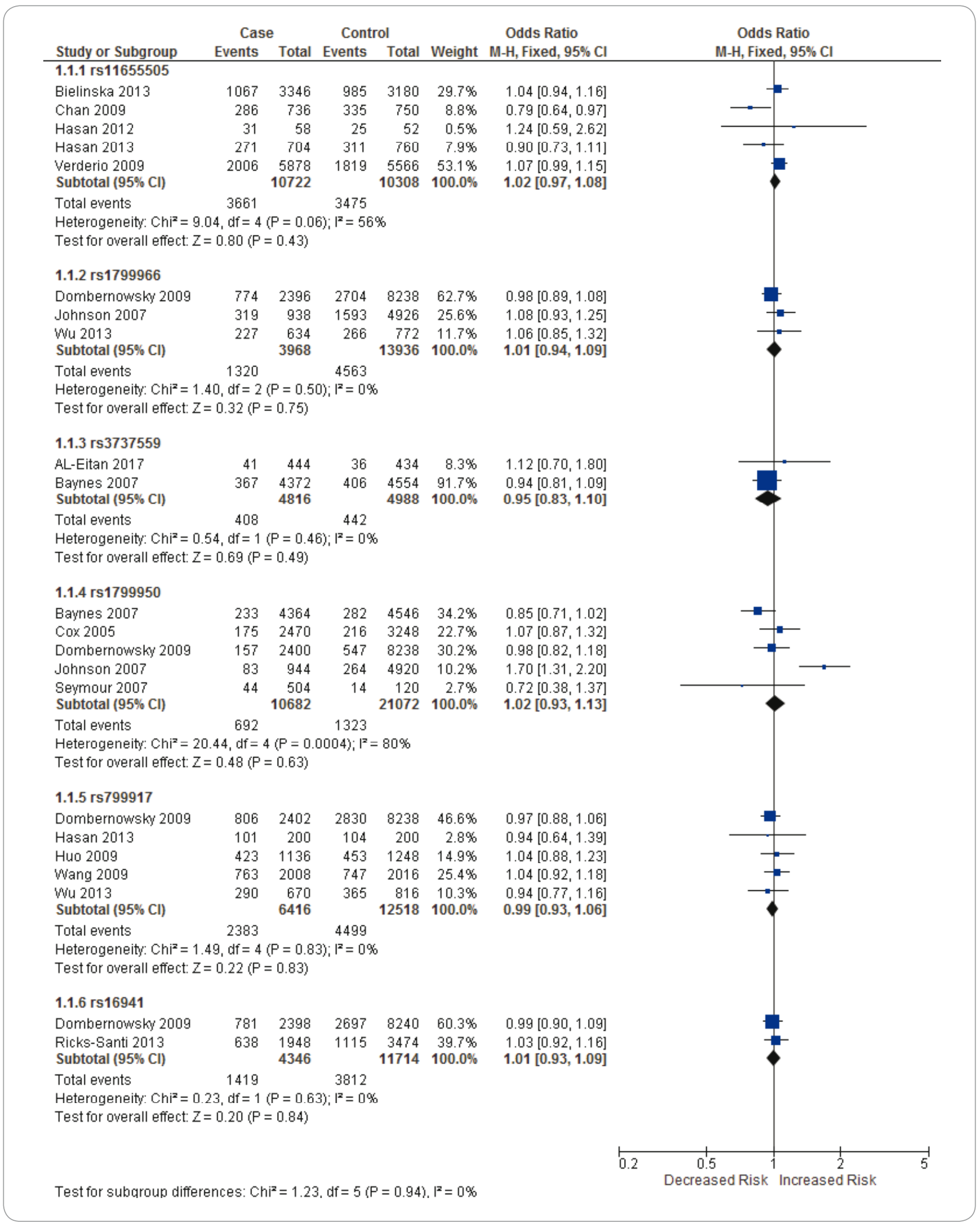

Graph 1. Forest plot of the risk for BRCA1 polymorphisms in allelic model. The error bars indicate $95 \% \mathrm{Cl}$. Solid squares represent each study in the meta-analysis. Solid diamonds represent pooled OR.

$\mathrm{Cl}$ - confidence interval, OR - odds ratio, $\mathrm{M}-\mathrm{H}$ - Mantel-Haenszel method 


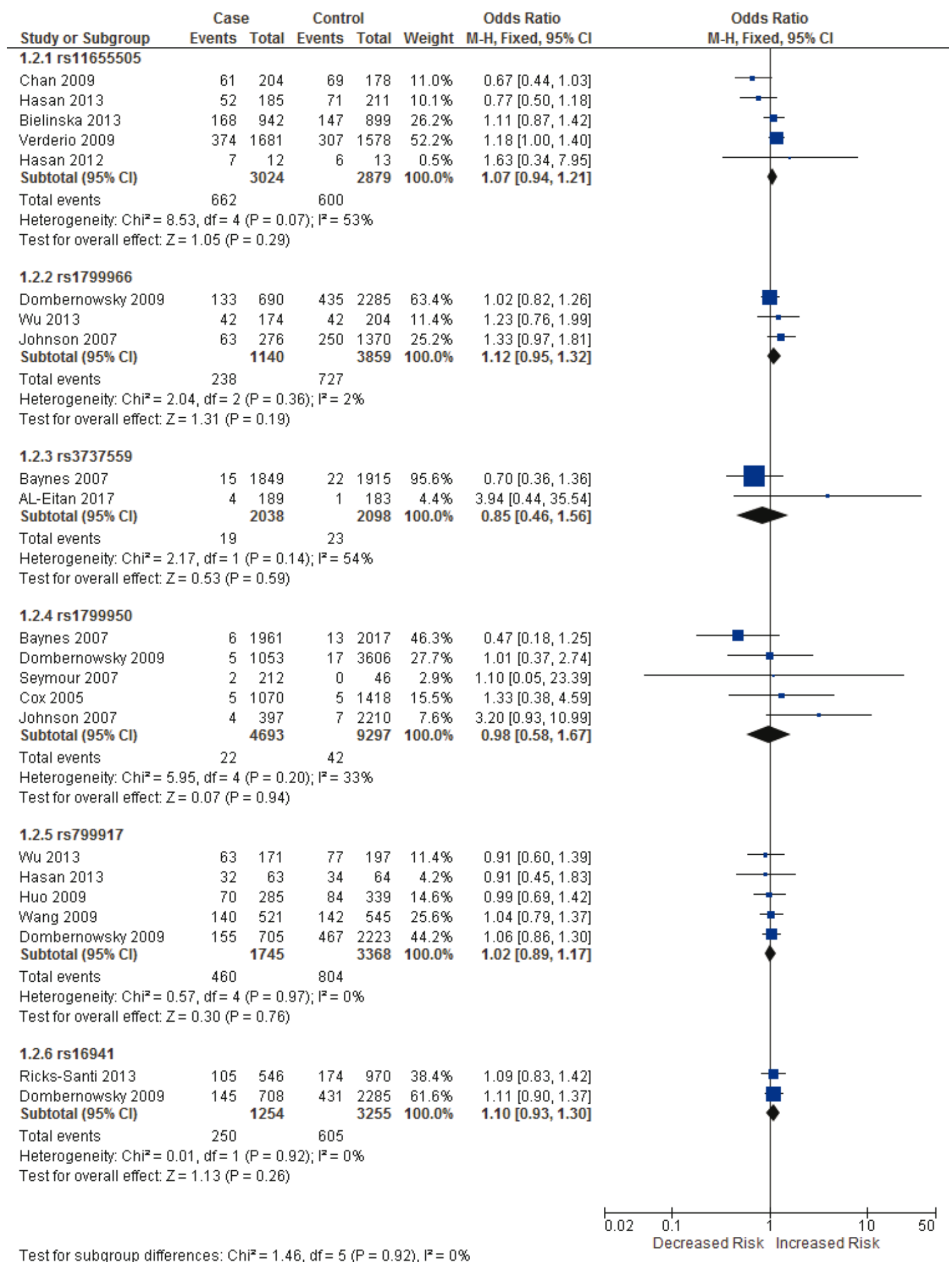

Graph 2. Forest plot of the risk for BRCA1 polymorphisms in homozygote model. The error bars indicate $95 \% \mathrm{Cl}$. Solid squares represent each study in the meta-analysis. Solid diamonds represent pooled OR.

$\mathrm{Cl}$ - confidence interval, $\mathrm{OR}$ - odds ratio, $\mathrm{M}-\mathrm{H}$ - Mantel-Haenszel method 


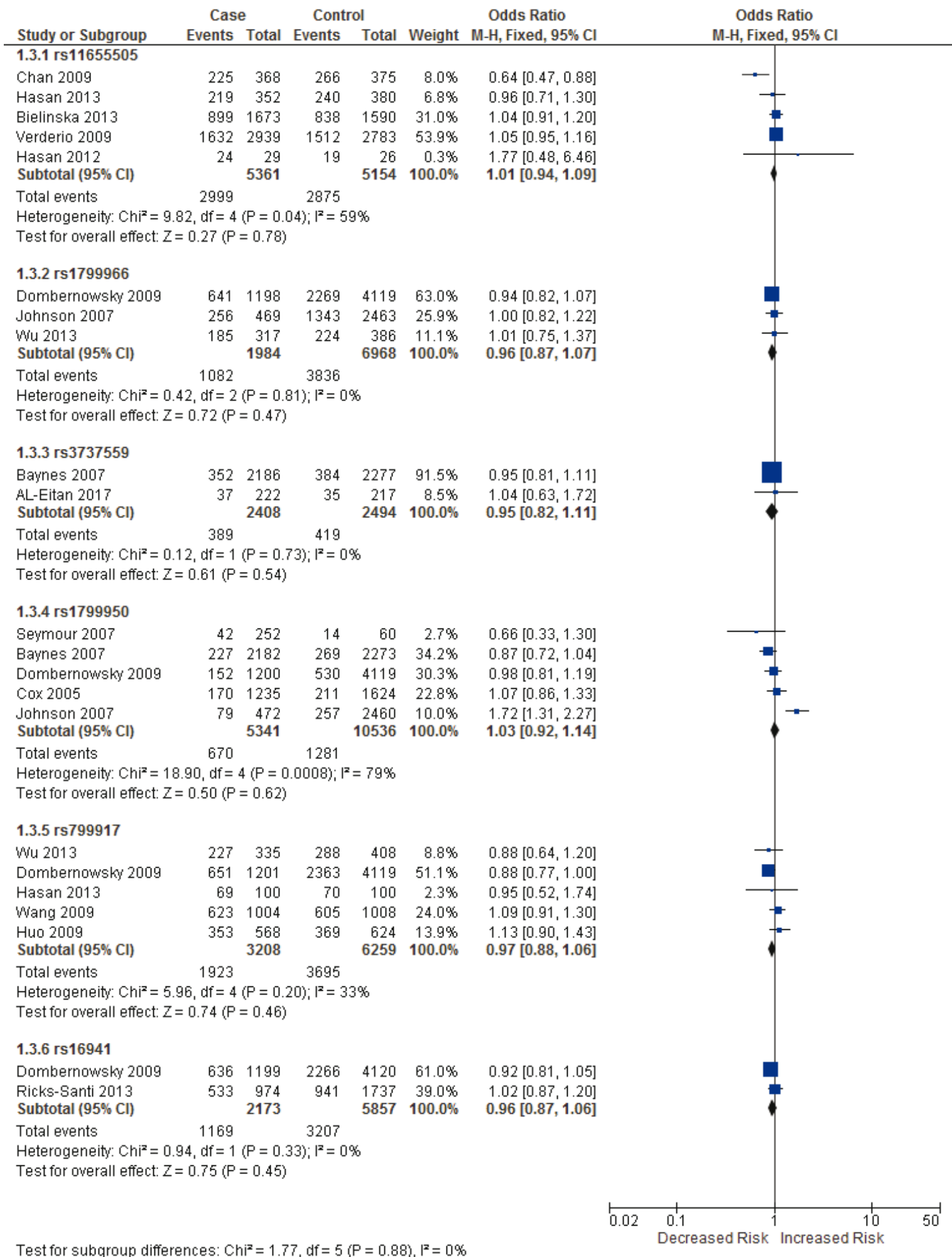




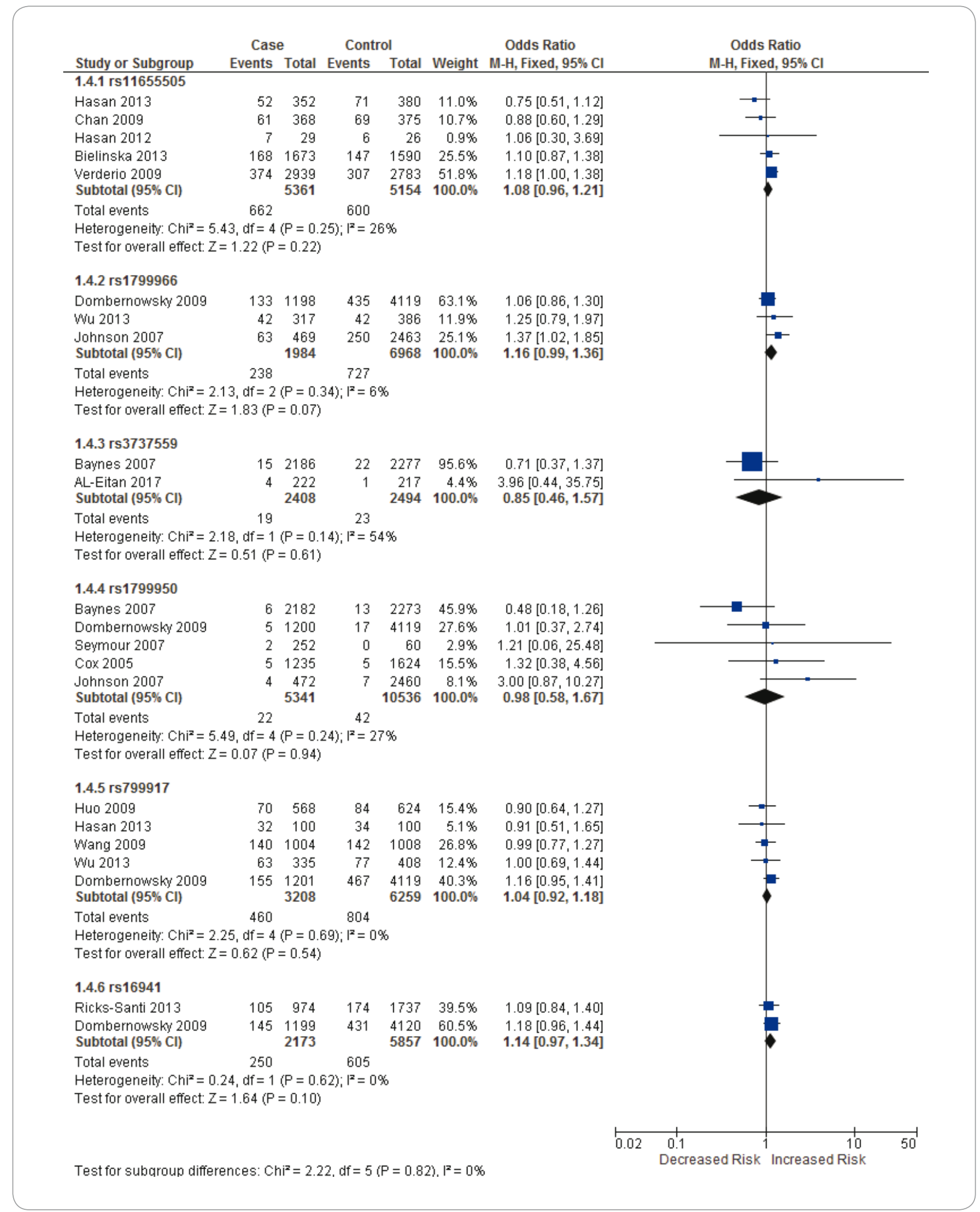

Graph 4. Forest plot of the risk for $B R C A 1$ polymorphisms in recessive model. The error bars indicate $95 \% \mathrm{Cl}$. Solid squares represent each study in the meta-analysis. Solid diamonds represent pooled OR.

$\mathrm{Cl}$ - confidence interval, $\mathrm{OR}$ - odds ratio, $\mathrm{M}-\mathrm{H}$ - Mantel-Haenszel method. 
These studies had NOS scores of 6 to 9 and assessed rs11655505 [9,13-16], rs1799966 [4,8,17], rs3737559 [10,18], rs1799950 [8,10,17,19,20], rs799917 $[4,17,21-23]$ or rs16941 [17,24]. Assessment of genotype distribution in control groups of all included researches showed their compliance with HWE. Tab. 1 shows the detailed information of included studies, such as first author's name, year of publication, ethnicity and genotype in the cases and controls in addition to the NOS score, chi-square and HWE $P$ values.

\section{Assessment of association between SNPs and BC risk}

None of the assessed SNPs were associated with $\mathrm{BC}$ risk in any of allelic, homozygote, dominant or recessive models (Graph 1-4). Besides, the funnel plots were depicted to evaluate the presence of publication bias in the meta-analysis of the mentioned SNPs in 4 genetic models. The overall results of the funnel plot showed fairly symmetrical shapes implying low probability of publication bias.

\section{Discussion}

Up to now, several BC predisposition factors including SNPs have been identified with either single-locus or epistatic effects which might be applied for BC risk assessment. Numerous strategies have been suggested to enhance accuracy of risk prediction programs with the hope of inclusion of informative SNPs in population-based risk screening programs [5]. Among putative informative SNPs for such programs are SNPs located in genes with significant role in BC. BRCA1 as the most significant genetic risk factor for $B C$ is a tumor suppressor gene involved in various cellular processes, such as maintenance of $X$ chromosome inactivation as well as the DNA damage response [25]. Other genes implicated in the repair of DNA double strand breaks are also associated with BC risk [4]. Previous studies have assessed the association of BRCA1 SNPs with $B C$ risk in distinct ethnic groups. In the present meta-analysis, we evaluated associations between six BRCA1 SNPs (rs11655505, rs1799966, rs3737559, rs1799950, rs799917 and rs16941) and $\mathrm{BC}$ risk using the pooled data of these publications. None of these SNPs resides in a known functional domain of BRCA 1 . Moreover, online tools for evaluation of the functional importance of missense variants, such as Align-GVGD and SIFT, have predicted them to be benign variants according to the low degree of conservation during evolution and minor biochemical alterations between the reference and variant amino acid [26]. The rs 11655505 (c. $-2265 C>T$ ) is located in the promoter region of $B R C A 1$ gene and enhances promoter activity [15]. The CT genotype of this SNP has been associated with decreased expression of BRCA1 [16]. The rs 1799966 (c.4837A>G (p.Ser1613Gly)) is a missense variant classified as a benign variant by expert panel. The rs3737559 (c.4357+117G>A) is an intronic variant located in IVS13. The rs1799950 (c.1067A>G (p.Gln356Arg)) and the rs799917 (c.2612C>G (p.Pro871 Arg)) are other missense variants classified as benign by expert panel. The rs16941 (c.3113A>G (p.Glu1038Gly)) is a missense variant with conflicting interpretations of pathogenicity.

We demonstrated lack of association between 6 SNPs within BRCA1 gene and $B C$ risk. The heterogeneity analysis showed the $\mathrm{I}^{2}$ values very small for rs1799966, rs799917 and rs16941 in all the genetic models, implying lack heterogeneity in these SNPs with $\mathrm{BC}$ risk. In addition, $I^{2}$ values for rs 3737559 were zero in allelic and dominant models. However, for the other two SNPs (rs11655505 and rs1799950), I $I^{2}$ values show the inconsistency between studies included in the meta-analysis. In addition to such heterogeneity, there were some other limitations in our study, including lack of ethnicity-based analysis and exclusion of studies written in other languages. In addition, we did not assess BC patients based on the molecular subtypes or environmental factors. However, the stringent quality check of included studies enhanced the reliability of our results.

Our study did not exclude the possible contribution of other SNPs within this gene in $\mathrm{BC}$ nor substantial contribution of multiple variants within this gene in conferring $B C$ risk. Evidence supporting the second possibility originated from a genome-wide association study in BC patients, which showed that single influence of most of these risk alleles were imperceptibly small. However, the risk conferred by multiple variants was significant suggesting consideration of a risk score through integration of a properly weighted calculation of all possibly functionalvariantswithin $B R C A 1$ and other genes [8].

\section{Conclusion}

The assessed SNPs within BRCA1 gene are not associated with $B C$ risk. Future studies with larger sample sizes in different ethnic populations and in distinct molecular subtypes of $\mathrm{BC}$ are needed to define the association of other SNPs in $B R C A 1$ gene with $B C$ risk.

\section{References}

1. Seifi-Alan M, Shamsi R, Ghafouri-Fard S et al. Expression analysis of two cancer-testis genes, FBXO39 and TDRD4, in breast cancer tissues and cell lines. Asian Pac J Cancer Prev 2014; 14(11): 6625-6629.

2. Khorshidi HR, Taheri M, Noroozi R et al. ANRIL genetic variants in Iranian breast cancer patients. Cell J 2017; 19 (Suppl 1): 72-78. doi: 10.22074/cellj.2017.4496.

3. Khorshidi HR, Taheri M, Noroozi R et al. Investigation of the association of HOTAIR single nucleotide polymorphisms and risk of breast cancer in an Iranian population. Iran J Cancer Prev 2017; 10(5): e7498

4. Wu HC, Delgado-Cruzata L, Machella N et al. DNA double-strand break repair genotype and phenotype and breast cancer risk within sisters from the New York site of the Breast Cancer Family Registry (BCFR). Cancer Cause Control 2013; 24(12): 2157-2168. doi: 10.1007/s10552-013-0292-z.

5. Sapkota Y. Germline DNA variations in breast cancer predisposition and prognosis: a systematic review of the literature. Cytogenet Genome Res 2014; 144(2): 77-91. doi: 10.1159/000369045.

6. Scully R, Livingston DM. In search of the tumoursuppressor functions of BRCA1 and BRCA2. Nature 2000; 408(6811): 429-432. doi: 10.1038/35044000.

7. Easton DF. How many more breast cancer predisposition genes are there? Breast Cancer Res 1999; 1(1): 14-17.

8. Johnson N, Fletcher O, Palles C et al. Counting potentially functional variants in BRCA1, BRCA2 and ATM predicts breast cancer susceptibility. Hum Mol Genet 2007; 16(9): 1051-1057. doi: 10.1093/hmg/ddm050.

9. Hasan TN, Grace BL, Shafi G et al. rs1 1655505 (c.-2265 $\mathrm{C} / \mathrm{T}$ ) variant in BRCA1 promoter is not associated with breast cancer risk in south India. Br J Med Med Res 2013; 3(1): 153-161. doi: 10.9734/BJMMR/2013/2082.

10. Baynes C, Healey CS, Pooley KA et al. Common variants in the ATM, BRCA1, BRCA2, CHEK2 and TP53 cancer susceptibility genes are unlikely to increase breast cancer risk. Breast Cancer Res 2007; 9(2): R27. doi: 10.1186/bcr1669.

11. Cao JJ, Luo CL, Yan R et al. rs15869 at miRNA binding site in BRCA2 is associated with breast cancer suscepti- 
bility. Med Oncol 2016; 33(12): 135. doi: 10.1007/s12032016-0849-2.

12. Stang A. Critical evaluation of the Newcastle-Ottawa scale for the assessment of the quality of nonrandomized studies in meta-analyses. Eur J Epidemiol 2010; 25(9): 603-605. doi: 10.1007/s10654-010-9491-z.

13. Bielinska B, Gaj P, Kluska A et al. Association of the BRCA1 promoter polymorphism rs 11655505 with the risk of familial breast and/or ovarian cancer. Fam Cancer 2013; 12(4): 691-698. doi: 10.1007/s10689-013-9647-6.

14. Chan KY, Liu W, Long JR et al. Functional polymorphisms in the BRCA1 promoter influence transcription and are associated with decreased risk for breast cance in Chinese women. J Med Genet 2009; 46(1): 32-39. doi: 10.1136/jmg.2007.057174.

15. Verderio P, Pizzamiglio S, Southey $M C$ et al. A BRCA1 promoter variant (rs11655505) and breast cancer risk. J Med Genet 2010; 47(4): 268-270. doi: 10.1136/jmg.2009.073544

16. Hasan TN, Grace BL, Shafi G et al. Association of BRCA1 promoter methylation with rs11655505
(c.2265C>T) variants and decreased gene expression in sporadic breast cancer. Clin Transl Oncol 2013; 15(7): 555-562. doi: 10.1007/s12094-012-0968-y.

17. Dombernowsky SL, Weischer M, Freiberg JJ et al. Mis sense polymorphisms in BRCA1 and BRCA2 and risk of breast and ovarian cancer. Cancer Epidemiol Biomarkers Prev 2009; 18(8): 2339-2342. doi: 10.1158/1055-9965.EPI09-0447.

18. Al-Eitan LN, Jamous RI, Khasawneh RH. Candidate gene analysis of breast cancer in the Jordanian population of Arab descent: a case-control study. Cancer Invest 2017; 35(4): 256-270. doi: 10.1080/07357907.2017.1289217.

19. Cox DG, Kraft P, Hankinson SE et al. Haplotype analysis of common variants in the BRCA1 gene and risk of sporadic breast cancer. Breast Cancer Res 2005; 7(2):R171-R175. doi: 10.1186/bcr973.

20. Seymour IJ, Casadei S, Zampiga V et al. Disease family history and modification of breast cancer risk in common BRCA2 variants. Oncol Rep 2008; 19(3): 783-786.

21. Wang $Z, X u$ Y, Tang J et al. A polymorphism in Werner syndrome gene is associated with breast cancer suscep- tibility in Chinese women. Breast Cancer Res Treat 2009; 118(1): 169-175. doi: 10.1007/s10549-009-0327-z.

22. Huo X, Lu C, Huang X et al. Polymorphisms in BRCA1, BRCA1-interacting genes and susceptibility of breast cancer in Chinese women. J Cancer Res Clin Oncol 2009; 135(11): 1569-1575. doi: 10.1007/s00432-009-0604-6. 23. Hasan TN, Shafi G, Syed NA et al. Lack of association of BRCA1 and BRCA2 variants with breast cancer in an ethnic population of Saudi Arabia, an emerging high-risk area. Asian Pac J Cancer Prev 2013; 14(10): 5671-5674.

24. Ricks-Santi LJ, Nie J, Marian C et al. BRCA1 polymorphisms and breast cancer epidemiology in the Western New York exposures and breast cancer (WEB) study. Genet Epidemiol 2013; 37(5): 504-511. doi: 10.1002/gepi.21730.

25. Jasin M. Homologous repair of DNA damage and tumorigenesis: the BRCA connection. Oncogene 2002; 21(58): 8981-8993. doi: 10.1038/sj.onc.1206176.

26. Cox DG, Simard J, Sinnett D et al. Common variants of the BRCA1 wild-type allele modify the risk of breast cancer in BRCA1 mutation carriers. Hum Mol Genet 2011; 20(23): 4732-4747. doi: 10.1093/hmg/ddr388. 